REFERENCES:

[1] Gossec, et al. Ann Rheum Dis 2016;68(2):418-29.

[2] Molto, et al. Ann Rheum Dis. 2018;77(1):124-127.

[3] Pedersen, et al. Arthritis Rheumatism 2016;68:418-29.

Disclosure of Interest: None declared

DOI: 10.1136/annrheumdis-2018-eular.4845

\section{FRI0214 CLINICAL EVALUATION CORRELATES POORLY WITH ULTRASOUND AND MAGNETIC RESONANCE IMAGING OF JOINTS AND ENTHESES IN EARLY PERIPHERAL SPONDYLOARTHRITIS}

T. Renson ${ }^{1}$, P. Carron ${ }^{1}$, S. Krabbe ${ }^{2}$, L. Jans ${ }^{3}$, A.-S. De Craemer ${ }^{1}$, M. de Hooge ${ }^{1}$ P. Jacques ${ }^{1}$, M. Ostergaard ${ }^{2}$, D. Elewaut ${ }^{1}$, F. Van den Bosch ${ }^{1} .{ }^{1}$ Rheumatology, Ghent University Hospital, Ghent, Belgium; ${ }^{2}$ Copenhagen Center for Arthritis Research (COPECARE), Center for Rheumatology and Spine Diseases, Rigshospitalet, Glostrup, Denmark; ${ }^{3}$ Radiology, Ghent University Hospital, Ghent, Belgium

Background: Enthesitis is a hallmark of spondyloarthritis ( $\mathrm{SpA})$, which occurs in $30 \%$ to $50 \%$ of psoriatic arthritis patients (pts). Evaluation of tenderness at the site of an enthesis with a standard palpation approach remains the gold standard for detection of enthesitis. However, inter- and intra-observer variability is rather high. All existing clinical enthesitis scoring systems lack validity. Imaging could avoid these drawbacks.

Objectives: To compare the performance of ultrasound (US) and magnetic resonance imaging (MRI) with clinical examination (CE) of joints and entheses in peripheral $(p) S p A$.

Methods: Clinical REmission in peripheral SPondyloArthritis (CRESPA) is a placebo-controlled trial of golimumab treatment in 60 early (symptom duration $<12$ weeks) pSpA pts. CE included tender and swollen joint count, dactylitis and enthesitis (evaluation of palpation tenderness) count. All pts underwent Power Doppler (PD)US of entheses and knee, talocrural (TC) and subtalar (ST) joints. Synovitis was scored according to the OMERACT-EULAR-US composite PDUS scale, giving a score of $0-3$ for each joint. Entheseal sites were evaluated for hypoechogenicity and intraenthesis Doppler signal and were scored on a scale of 0-3 Modified whole-body MRI was performed at baseline. Bone marrow oedema (BME), synovitis and soft tissue inflammation (STI) were scored (scale $0-3$ ) by 3 readers at several anatomical sites of pelvis and lower limbs. For each site a mean of the scores of the 3 readers was calculated.

Results: Abstract FRI0214 - Table 1. Prevalence of synovitis and enthesitis on CE, US and MRI

\begin{tabular}{lccc}
\hline Joints/entheses & CE & US & MRI \\
\hline Hip joint & $3 / 60(0)$ & - & $4 / 60^{1}$ \\
Knee joint & $21 / 60^{6}$ & $25 / 60^{8}$ & $24 / 60^{7}$ \\
Talocrural joint & $14 / 60^{1}$ & $9 / 60^{1}$ & $24 / 60^{13}$ \\
Subtalar joint & $7 / 60^{2}$ & $10 / 60^{12}$ & $15 / 60(0)$ \\
Quadriceps tendon & $10 / 60^{2}$ & $9 / 60^{1}$ & $4 / 60(0)$ \\
Superior patellar ligament & $8 / 60^{2}$ & $8 / 60^{1}$ & $7 / 60^{3}$ \\
Inferior patellar ligament & & & $6 / 60^{1}$ \\
Achilles tendon & $14 / 60^{2}$ & $11 / 60^{2}$ & $17 / 60^{4}$ \\
Plantar fascia & $15 / 60^{4}$ & $7 / 60^{1}$ & $17 / 60^{9}$ \\
\hline
\end{tabular}

Prevalence of bilateral involvement is indicated between brackets.

Synovitis detected by US and MRI was most prevalent at knee joints (table 1). A discrepancy was noted between TC synovitis detected by CE, US and MRI. Enthesitis was most prevalent at Achilles tendon and plantar fascia. Regarding enthesitis, agreement between CE and US ranged from no (kappa -0.082) to moderate agreement (kappa 0.562). The highest agreement was observed at the entheseal sites of Achilles tendon (left 0.511, right 0.350) and plantar fascia (left 0.321 , right 0.507 ). MRI did not correlate better with CE than US (kappa from -0.077 to 0.446 ). The correlation between MRI and US was overall poor and only in the Achilles tendon moderate (range -0.106 to 0.656 ).

Conclusions: There was a weak agreement between CE and imaging in detecting enthesitis. In general, US detects less enthesitis compared to CE, while MRI detects more.

\section{REFERENCE:}

[1] Gladmann DD, Chadran V. Observational cohort studies: Lessons learnt from the university of Toronto Psoriatic Arthritis Program. Rheumatology $2011 ; 50(1): 25-31$

Disclosure of Interest: None declared DOI: 10.1136/annrheumdis-2018-eular.4420

\section{FRI0215}

\section{ASAS CONSENSUS ON SPANISH NOMENCLATURE} FOR SPONDYLOARTHRITIS

V. Navarro-Compán ${ }^{1}$, T. Otón ${ }^{2}$, E. Loza ${ }^{2}$, R. Almodóvar ${ }^{3}$, R. Ariza-Ariza ${ }^{4}$, W. Bautista-Molano ${ }^{5}$, R. Burgos-Vargas ${ }^{6}$, E. Collantes-Estévez ${ }^{7}$, E. de Miguel $^{1}$ C. González-Fernández ${ }^{8}$, J. Gratacós-Masmitja ${ }^{9}$, S. Ibáñez ${ }^{10}$, X. Juanola ${ }^{11}$, J. Maldonado-Cocco ${ }^{12}$, A. Moltón ${ }^{13}$, J. Mulero-Mendoza ${ }^{14}$, C. Pacheco-Tena ${ }^{15}$, C. Ramos-Remus ${ }^{16}$, J. Sanz Sanz ${ }^{14}$, R. Valle-Oñate ${ }^{5}$, P. Zarco ${ }^{3}$, H. MarzoOrtega ${ }^{17} .{ }^{1} \mathrm{H}$. La Paz, IdiPaz, Madrid, Spain; ${ }^{2}$ INMUSC; ${ }^{3} \mathrm{HF}$. Alcorcón, Madrid; ${ }^{4} \mathrm{H}$. V. Macarena, Sevilla, Spain; ${ }^{5} \mathrm{H}$. Militar, Bogotá, Colombia; ${ }^{6} \mathrm{H}$. General, $D F$, Mexico: ${ }^{7}$ H. R. Sofía, Córdoba; ${ }^{8}$ H. Clínico, Madrid; ${ }^{9} \mathrm{H}$. Parc-Taulí, Sabadell, Spain; ${ }^{10} \mathrm{C}$. Alemana, Santiago, Chile; ${ }^{11} \mathrm{H}$. Bellvitge, Barcelona, Spain; ${ }^{12} \mathrm{~F}$. Medicina, Uni. Buenos Aires, Buenos Aires, Argentina: ${ }^{13} \mathrm{H}$. Cochin, Paris, France; ${ }^{14} \mathrm{H}$. Puerta Hierro, Madrid, Spain; ${ }^{15} \mathrm{U}$. Autónoma, Chihuahua; ${ }^{16}$ Univ. Autonoma de GDL, GDL, Mexico; ${ }^{17}$ NIHR LBRC and LIRMM, UoL, Leeds, UK

Background: In the last three decades, major advances in the spondyloarthritis (SpA) field have been achieved leading to new terminology. Whilst this terminology is well established in English, there is concern about the disparity of translated words and acronyms in Spanish, which is used by more than 437 million people in 21 countries.

Objectives: To develop a consensus to standardise the use of the Spanish terms, abbreviations and acronyms employed in the field of SpA.

Methods: An international task force was created comprising of all ASAS Spanish-speaking native members representing 5 countries, the executive committee members of GRESSER, two methodologists, two linguists from Real Academia Nacional de la Medicina Española (RANM) and two patients from CEADE. First, a literature review spanning the last 15 years was performed to identify the conflicting terms/abbreviations/acronyms. This review examined available written sources in Spanish including manuscripts, ICF and ICD, guidelines, recommendations and consensus. A three-round Delphi method including a face-to-face meeting, then followed. The recommendations from the RANM based on the Panhispanic dictionary in medical terms were consistently followed throughout the process.

Results: Consensus was reached for 44 terms, abbreviations or acronyms related to the field of SpA. A Spanish translation was accepted for 6 terms and 6 abbreviations to name the disease or its subgroups (SpA, axSpA, nr-axSpA, $\mathrm{pSpA}, \mathrm{AS}, \mathrm{r}-\mathrm{SpA}, \mathrm{PsA}$ ) and for 6 terms and 4 abbreviations related with the dis ease (enthesitis, sacroiliitis, IBP, MRI-SIJ, BME, mNY). Additionally, it was agreed not to translate into Spanish 15 acronyms because they are very well established (ASDAS, BASDAI, BASFI, BASMI, mSASSS, RASS, BASRI, BAS-G, ASQoL, PSAQoL, MASES, MASEI, PASI, PARS, ASAS). However, when mentioning these acronyms, it is recommended that the following structure is used: type of variable in Spanish and acronym and expanded form in English. With regards to the terms or abbreviations attached to 7 acronyms (ASDAS-CI, ASDAS-MI, ASAS-HI, ASASpr, ASAS 5/6, ASAS20, ASAS40 improvement criteria), it was agreed to translate only the expanded form and a translation was also selected for all of them.

Conclusions: A consensus in Spanish nomenclature for SpA has been developed by ASAS group. The implementation of this consensus across the Spanish speaking community will be of substantial benefit, avoiding misunderstandings and time-consuming processes.

Acknowledgements: GRESSER(E. Galíndez, J. Gotor, M. Moreno, J. Quirós, A. Urruticoechea), CEADE(P. Plazuelo, M. Garrido), RANM(C. González, C. Remacha)

Disclosure of Interest: None declared

DOI: 10.1136/annrheumdis-2018-eular.2796

\section{FRI0216 DETECTION OF STRUCTURAL LESIONS ON T1 WEIGHTED MRI VERSUS RADIOGRAPHY OF THE S JOINTS IN EARLY AXIAL SPONDYLOARTHRITIS: 2- YEAR DATA}

W.P. Maksymowych ${ }^{1}$, P. Claudepierre ${ }^{2}$, M. de Hooge ${ }^{3}$, R.G. Lambert ${ }^{1}$, R. Landewé ${ }^{4}$, A. Molto ${ }^{5}$, D. van der Heijde ${ }^{3}$, J.F. Bukowski ${ }^{6}$, H. Jones $^{6}$, I. Logeart ${ }^{7}$ L. Marshall ${ }^{6}$, R. Pedersen ${ }^{6}$, A. Szumski ${ }^{8}$, B. Vlahos ${ }^{6}$, M. Dougados ${ }^{5} .{ }^{1}$ University of Alberta, Edmonton, Canada; ${ }^{2}$ Universite Paris Est Creteil, Creteil, France; ${ }^{3}$ Leiden University Medical Center, Leiden; ${ }^{4}$ Amsterdam Rheumatology and Immunology Center, Amsterdam, Netherlands; ${ }^{5}$ Paris Descartes University, Hôpital Cochin, Paris, France; ${ }^{6}$ Pfizer, Collegeville, USA; ${ }^{7}$ Pfizer France, Paris, France; ${ }^{8}$ inVentiv Health, Princeton, USA

Background: Sacroiliac joint (SIJ) structural damage may be evaluated using MRI, CT scan or radiographs.

Objectives: A post-hoc analysis of SIJ images from EMBARK (NCT01258738) and DESIR (NCT01648907) evaluated: ${ }^{1}$ association between presence/absence of erosion on MRI and presence/absence of erosion or sacroiliitis on radiographs 
at $\mathrm{BL}$ and $\mathrm{Wk} 104 ;^{2}$ association between decrease/increase in erosion score on $\mathrm{MRI}$ and decrease/increase in erosion or sacroiliitis grade on radiographs, BL to Wk 104.

Methods: All patients had early axSpA. EMBARK: 12 wks double-blind placebocontrol, then 92 wks open-label etanercept. DESIR: patients had no history of biologics and received no biologics for 104 wks. MRI images from both studies: combined, anonymized, and read per patient; radiographs combined, anonymized, read separately from MRI. Readers unaware of: image chronology, original cohort. Three experienced readers individually reviewed T1 weighted MRI using SpondyloArthritis Research Consortium of Canada SIJ Structural Score; 3 different readers assessed radiographic sacroiliitis using $\mathrm{mNY}$ grade; all were at level of each joint surface. Lesion presence/absence or decrease/increase recorded per patient if $\geq 2$ of 3 readers agreed. Statistical analyses: $\kappa$ coefficient of agreement, McNemar's test for discordance asymmetry.

Results: 224 patients had MRI and radiographs. At BL, concordance for presence or absence of erosion in 162/224 (72.3\%) ( $\kappa=0.42)$, table 1. Discordance: erosion more frequent on MRI $(21.4 \%)$ than radiographs $(6.3 \% ; p<0.0001)$. Wk 104 data similar to BL. Decrease in erosion more frequent than increase only on $\mathrm{MRI}$; significantly more frequent on MRI than radiographs. Decrease in erosion on $\mathrm{MRI}$ significantly more frequent than decrease in sacroiliitis grade.

Abstract FRI0216 - Table 1. Concordance between MRI and Radiographs, BL and Wk 104; and Change BL to Wk 104

\begin{tabular}{|c|c|c|c|c|c|c|c|}
\hline & $\mathrm{N}$ & $\begin{array}{c}\text { Present/ } \\
\text { Present } \\
\mathrm{n}(\%)\end{array}$ & $\begin{array}{c}\text { Absent/ } \\
\text { Absent } \\
\mathrm{n}(\%)\end{array}$ & $\begin{array}{c}\text { Absent/ } \\
\text { Present } \\
\mathrm{n}(\%)\end{array}$ & $\begin{array}{c}\text { Present/ } \\
\text { Absent } \\
\mathrm{n}(\%)\end{array}$ & $\begin{array}{c}\kappa \\
(95 \% \mathrm{Cl})\end{array}$ & P-value* \\
\hline $\begin{array}{l}\text { BL Erosion: MRI/ } \\
\text { radiographs }\end{array}$ & 224 & $\begin{array}{c}50 \\
(22.3)\end{array}$ & $\begin{array}{c}112 \\
(50.0)\end{array}$ & $\begin{array}{c}14 \\
(6.3)\end{array}$ & $\begin{array}{c}48 \\
(21.4)\end{array}$ & $\begin{array}{c}0.42 \\
(0.30- \\
0.53)\end{array}$ & $<0.0001$ \\
\hline $\begin{array}{l}\text { Wk } 104 \text { Erosion: MRI/ } \\
\text { radiographs }\end{array}$ & 222 & $\begin{array}{c}44 \\
(19.8)\end{array}$ & $\begin{array}{c}119 \\
(53.6)\end{array}$ & $\begin{array}{c}15 \\
(6.8)\end{array}$ & $\begin{array}{c}44 \\
(19.8)\end{array}$ & $\begin{array}{c}0.41 \\
(0.29- \\
0.53)\end{array}$ & 0.0002 \\
\hline $\begin{array}{l}\mathrm{BL} \text { : Erosion on MRI/ } \\
\text { sacroiliitis on } \\
\text { radiographs }\end{array}$ & 224 & $\begin{array}{c}60 \\
(26.8)\end{array}$ & $\begin{array}{c}97 \\
(43.3)\end{array}$ & $\begin{array}{c}29 \\
(12.9)\end{array}$ & $\begin{array}{c}38 \\
(17.0)\end{array}$ & $\begin{array}{c}0.39 \\
(0.26- \\
0.51)\end{array}$ & 0.27 \\
\hline $\begin{array}{l}\text { Wk 104: Erosion on } \\
\text { MRI/sacroiliitis on } \\
\text { radiographs }\end{array}$ & 222 & $\begin{array}{c}56 \\
(25.2)\end{array}$ & $\begin{array}{c}99 \\
(44.6)\end{array}$ & $\begin{array}{c}35 \\
(15.8)\end{array}$ & $\begin{array}{c}32 \\
(14.4)\end{array}$ & $\begin{array}{c}0.37 \\
(0.25- \\
0.50)\end{array}$ & 0.71 \\
\hline $\begin{array}{l}\text { Erosion decrease: } \\
\text { MRI/radiographs }\end{array}$ & 221 & $4(1.8)$ & $\begin{array}{c}162 \\
(73.3)\end{array}$ & $6(2.7)$ & $\begin{array}{c}49 \\
(22.2)\end{array}$ & $\begin{array}{c}0.06 \\
(-0.05 \\
0.16)\end{array}$ & $<0.0001$ \\
\hline $\begin{array}{l}\text { Erosion increase: } \\
\text { MRI/radiographs }\end{array}$ & 221 & $2(0.9)$ & $\begin{array}{c}187 \\
(84.6)\end{array}$ & $\begin{array}{c}17 \\
(7.7)\end{array}$ & $15(6.8)$ & $\begin{array}{c}0.03 \\
(-0.12 \\
0.18)\end{array}$ & 0.72 \\
\hline $\begin{array}{l}\text { Erosion decrease on } \\
\mathrm{MRI} / \text { sacroiliitis grade } \\
\text { decrease on } \\
\text { radiographs }\end{array}$ & 221 & $8(3.6)$ & $\begin{array}{c}154 \\
(69.7)\end{array}$ & $\begin{array}{c}14 \\
(6.3)\end{array}$ & $\begin{array}{c}45 \\
(20.4)\end{array}$ & $\begin{array}{c}0.08 \\
(-0.05 \\
0.21)\end{array}$ & $<0.0001$ \\
\hline $\begin{array}{l}\text { Erosion increase on } \\
\mathrm{MRI} / \text { sacroilitis grade } \\
\text { increase on } \\
\text { radiographs }\end{array}$ & 221 & $4(1.8)$ & $\begin{array}{c}180 \\
(81.4)\end{array}$ & $\begin{array}{c}24 \\
(10.9)\end{array}$ & $13(5.9)$ & $\begin{array}{c}0.09 \\
(-0.07 \\
0.25)\end{array}$ & 0.07 \\
\hline
\end{tabular}

*McNemar's test for discordance asymmetry.

$\mathrm{BL}$, baseline; Wk, Week.

Conclusions: Findings of SIJ structural damage are observed differently on radiography and $\mathrm{MRI}$ in patients with early axSpA, and may appear to evolve differently.

Disclosure of Interest: W. Maksymowych Grant/research support from: AbbVie, Pfizer, Consultant for: Abbvie, Janssen, Lilly, Merck, Novartis, Pfizer, UCB, P. Claudepierre Consultant for: Abbvie, BMS, Celgene, Janssen, Novartis, Merck, Pfizer, Roche, UCB, Lilly, M. de Hooge Employee of: Selfemployed without other personnel (registered company under the Belgium law) MdH Research. Additional Affiliation: Ghent University, Ghent, Belgium, R. Lambert Consultant for: AbbVie, Bioclinica, Janssen, Parexel, UCB, R. Landewé Grant/research support from: Abbott, Amgen, Centocor, Novartis, Pfizer, Roche, Schering-Plough, UCB, Consultant for: AbbVie, Ablynx, Amgen, Astra-Zeneca, Bristol Myers Squibb, Celgene, Janssen, Galapagos, GlaxoSmithKline, Novartis, Novo-Nordisk, Merck, Pfizer, Roche, Schering-Plough, TiGenix, UCB, Employee of: Director of Rheumatology Consultancy BV, which is a registered company under Dutch law, Speakers bureau: Abbott/AbbVie, Amgen, Bristol Myers Squibb, Janssen, Merck, Pfizer, Roche, Schering-Plough, UCB, A. Molto Grant/research support from: Pfizer, Consultant for: Merck, UCB, D. van der Heijde Consultant for: AbbVie, Amgen, Astellas, AstraZeneca, BMS, Boehringer Ingelheim, Celgene, Daiichi, Lilly, Galapagos, Gilead, GlaxoSmithKline, Janssen, Merck, Novartis, Pfizer, Regeneron, Roche, Sanofi, Takeda, UCB, Employee of: Director of Imaging Rheumatology bv, J. Bukowski Shareholder of: Pfizer, Employee of: Pfizer, H. Jones Shareholder of: Pfizer, Employee of: Pfizer, I. Logeart Shareholder of: Pfizer, Employee of: Pfizer, L. Marshall Shareholder of: Pfizer, Employee of: Pfizer, R. Pedersen Shareholder of: Pfizer, Employee of: Pfizer, A. Szumski
Employee of: InVentiv Health, B. Vlahos Shareholder of: Pfizer, Employee of: Pfizer, M. Dougados Grant/research support from: Pfizer, AbbVie, UCB, Merck and Lilly, Consultant for: Pfizer, AbbVie, UCB, Merck and Lilly DOI: 10.1136/annrheumdis-2018-eular.2124

\section{FRI0217 DIAGNOSTIC ASCERTAINMENT OF AXIAL SPONDYLOARTHRITIS IN PATIENTS PRESENTING WITH UNDIAGNOSED BACK PAIN: WHAT IS THE IMPACT OF MRI IN RHEUMATOLOGICAL PRACTICE?}

R.G. Lambert ${ }^{1}$, R. Carmona ${ }^{2}$, J. Yeung ${ }^{3}$, J. Chan ${ }^{4}$, L. Martin ${ }^{5}$, S. Aydin ${ }^{6}$, D. Mosher ${ }^{5}$, A. Masetto ${ }^{7}$, S. Keeling ${ }^{8}$, O. Ziouzina ${ }^{5}$, S. Rohekar', J. Paschke ${ }^{10}$ A. Carapellucci ${ }^{10}$, W.P. Maksymowych ${ }^{8,10}$. ${ }^{1}$ Radiology, University of Alberta, Edmonton; ${ }^{2}$ St. Joseph's Healthcare Hamilton, Hamilton; ${ }^{3}$ James Yeung Rheumatology, Richmond; ${ }^{4}$ Artus Health Clinic, Vancouver, ${ }^{5}$ University of Calgary, Calgary; ${ }^{6}$ Ottawa Hospital, Ottawa; ${ }^{7}$ Université de Sherbrooke, Sherbrooke; ${ }^{8}$ Medicine, University of Alberta, Edmonton; ${ }^{9}$ Lawson Health Research Institute, London; ${ }^{10}$ CaRE Arthritis Ltd., Edmonton, Canada

Background: In current rheumatology practice, the circumstances that prompt clinicians to order MRI in patients with suspected axSpA are unclear. In addition, the manner and degree to which MRI changes diagnostic ascertainment of axSpA in patients presenting with undiagnosed back pain has not been formally studied. Objectives: 1. To determine whether any particular patient demographic and/or disease characteristics are associated with rheumatologist ordering of MRI. 2. To assess the impact of MRI evaluation on diagnostic ascertainment of axial SpA in patients presenting with undiagnosed back pain.

Methods: The multicenter Screening for AxSpA in Psoriasis, Iritis, and Colitis (SASPIC) Study is aimed at early detection of axial SpA in consecutive patients presenting with undiagnosed back pain to the rheumatologist. Consecutive patients with any one of psoriasis, iritis, or colitis diagnosed by the relevant specialist undergo routine evaluation by a rheumatologist. The rheumatologist determines the presence/absence of axial SpA and the degree of confidence in the diagnosis ( -10 (definitely not SpA) to +10 (definite $\mathrm{SpA}$ ) on a NRS) at 3 consecu tive stages: 1. After the clinical evaluation; 2. After the results of labs (B27, CRP) and radiography; 3 . After the results of MRI. Differences in patient demographics and/or disease characteristics between those who did or did not have MRI were assessed by chi-square and t-tests. We assessed the degree of diagnostic reclassification after each step at the categorical level (axial SpA yes/no) and also according to the degree of confidence.

Results: 244 patients $(51.6 \%$ male, mean age 34.6 years, mean age at symptom onset 27.4 years, mean back pain duration 7.1 years, $B 27+37.2 \%$ ) were referred with AAU (29.9\%), psoriasis (21.7\%), Crohn's colitis $(32.8 \%)$, ulcerative colitis (19.3\%). A diagnosis of axSpA was made in $67.5 \%$ after stage 1 clinical evaluation and in $56.4 \%$ at stage 2 after review of the labs and radiography. MRI evaluation varied across sites (mean(range): $73 \%(16.7 \%>100 \%)$ of patients), ordered in 141 patients, and significantly more frequently in those with probable inflammatory type back pain (probability $>5(0-10$ scale) $(p=0.04)$, when radiography was $m N Y-(p=0.005)$ and in those without Crohn's colitis $(p=0.001)$. No differences in ordering of MRI were noted according to age, gender, disease duration, back pain severity, NSAID response, B27 status, or CRP level. In patients with completed $\mathrm{MRI}$ scans, a diagnosis of axSpA was made in $70.5 \%$ after stage 1 clinical evaluation, in $56.4 \%$ after review of the labs and radiography, and in $47.3 \%$ after MRI review. 24 (18.6\%) were recategorized from SpA to non-SpA and 4 (3.1\%) from non-SpA to SpA. Confidence in diagnostic categorization was increased after MRI.

\begin{tabular}{|c|c|c|c|c|}
\hline $\begin{array}{c}\text { Stage of } \\
\text { Assessment }\end{array}$ & $\begin{array}{c}\text { axSpA present } \\
\text { n (\%) }\end{array}$ & $\begin{array}{l}\text { Mean (SD) } \\
\text { confidence }\end{array}$ & $\begin{array}{c}\text { axSpA absent } \\
\text { n (\%) }\end{array}$ & $\begin{array}{l}\text { Mean (SD) } \\
\text { confidence }\end{array}$ \\
\hline 1. Clinical only & $\mathrm{n}=91(70.5)$ & $5.5(2.4)$ & $n=38(29.5)$ & $3.4(3.2)$ \\
\hline $\begin{array}{l}\text { 2. Clinical plus } \\
\text { labs and } \\
\text { radiography }\end{array}$ & $\mathrm{n}=81(62.8)$ & $5.9(2.9)$ & $\mathrm{n}=48(37.2)$ & $5.1(3.6)$ \\
\hline $\begin{array}{l}\text { 3. Clinical, labs, } \\
\text { radiography, plus } \\
\text { MRI }\end{array}$ & $\mathrm{n}=61(47.3)$ & $7.5(2.9)$ & $\mathrm{n}=68(52.7)$ & $7.5(2.5)$ \\
\hline
\end{tabular}

Conclusions: In a setting of undiagnosed back pain and higher risk for axial SpA, use of MRI is primarily driven by negative radiography. MRI was primarily helpful in ruling out SpA and reducing false positives.

Disclosure of Interest: None declared

DOI: 10.1136/annrheumdis-2018-eular.4841 